\title{
Heat induced colour changes of pine (Pinus pinaster) and eucalypt (Eucalyptus globulus) wood
}

Bruno Esteves1, António Velez Marques2, Idalina Domingos1 And HELENA PEREIRA3

1Department of Wood Engineering, Superior School of Technology of Viseu, Polytechnic Institute of Viseu, Portugal

2 Research Centre for Chemical Engineering and Biotechnology (CIEQB), Superior Institute of Engineering of Lisbon, Portugal Portugal

3 Forest Research Centre, School of Agronomy, Technical University of Lisbon,,

Email: bruno@demad.estv.ipv.pt

Fax: 0351232424651

Phone: 0351-232480645 or 0351-919056830

\section{Acknowledgement}

The authors would like to thank Wood Science and Technology for this publication. The original publication is available at

http://www.Springerlink.com/content/e1j508p0g404 $\underline{1576 /}$

\section{Reference}

Esteves, B., Velez Marques, A., Domingos, I., Pereira, H 2008 Heat induced colour changes of pine (Pinus pinaster) and eucalypt (Eucalyptus globulus) wood. Wood Science and Technology. 42(5) 369-384. DOI : 10.1007/s00226-007-0157-2 


\section{Abstract}

Heat treatment of Pinus pinaster and Eucalyptus globulus wood was made by hot air in an oven during 2 to $24 \mathrm{~h}$ at $170-200{ }^{\circ} \mathrm{C}$ and by steam in an autoclave during 2 to $12 \mathrm{~h}$ at $190-210{ }^{\circ} \mathrm{C}$. The colour parameters $L^{*}, a^{*}$ and $b^{*}$ were determined by the CIELAB method on radial, tangential and transverse sections for untreated and treated wood, and their variation with the treatment $\left(\Delta \mathrm{L}^{*}, \Delta \mathrm{a}^{*}\right.$ and $\left.\Delta \mathrm{b}^{*}\right)$ were calculated in percent.

In the untreated woods, for eucalypt wood lightness $\left(\mathrm{L}^{*}\right)$ varied between $54.1-63.8 \%$ with a* between 7.4-8.5 and $b^{*}$ 15.7-19.9, and for pine wood $\mathrm{L}^{*}$ varied between $67.3-76.1 \%$, $\mathrm{a}^{*}$ between 6.9 -7.6 and $b^{*} 16.3-24.1$. With the heat treatment wood became darker, more for oven treatment $\left(\Delta \mathrm{L}^{*}\right.$ about $50 \%$ for $4 \%$ mass loss), and at the same treatment conditions more for eucalypt wood. In general the contribution of the red colour $\left(\mathrm{a}^{*}\right)$ and yellow $\left(\mathrm{b}^{*}\right)$ decreased with the heat treatment. The transverse section darkened less in the two species and for both treatments, with small differences between radial and tangential sections. Lightness decrease was related to chemical changes, with good correlations with glucose $\left(R^{2}=0.96\right)$, hemicelluloses $\left(R^{2}=0.92\right)$ and lignin $\left(R^{2}=0.86\right)$.

As regards colour, the heat treatments showed an interesting potential to improve the wood quality for solid timber products from pine and eucalypt. 


\section{Introduction}

The use of heat treatments to modify the properties of wood is not new and Tiemann (1920) already reported that high temperature drying decreased the wood equilibrium moisture content and swelling as well as Stamm and Hansen (1937) with wood heated in several gases. The first studies directed towards improvement of wood dimensional stability were carried out by Stamm et al. (1946) and further continued by Kollmann and Schneider (1963), Kollmann and. Fengel (1965), Fengel (1966), D'Jakonov and Konepleva (1967), Nikolov and Encev (1967), Burmester (1973), Rusche (1973 a, b), Giebeler. (1983), Hillis (1984), Bourgois and Guyonnet (1988), Bourgois et al. (1989) and Dirol and Guyonnet (1993).

The development and commercialization of heat treatments to increase wood durability and dimensional stability was stimulated only recently by environmental concerns but there are already several commercial applications in some European countries and North America.

The heat treatments reduce the equilibrium moisture content of wood and improve its dimensional stability and durability but may reduce the mechanical resistance, mainly of bending (Kollmann and Schneider 1963; Viitanen et al. 1994; Viitaniemi et al. 1997; Kim et al. 1998; Kubojima et al. 2000; Epmeier et al. 2001; Jämsä and Viitaniemi 2001; Rapp and Sailer 2001; Kamdem et al. 2002; Yildiz 2002; Bengtsson et al. 2002; Bekhta and Niemz 2003; Gosselink et al. 2004; MetsäKortelainen et al. 2006; Wang and Cooper 2005; Hakkou et al. 2006; Esteves et al. 2007).

The heat treatment of wood changes its chemical composition by degrading both cell wall compounds and extractives. The thermal degradation starts by deacetylation of hemicelluloses and the released acetic acid acts as a depolymerization catalysist which further increases polysaccharide decomposition (Tjeerdsma et al. 1998; Sivonen et al. 2002; Nuopponen et al. 2004). Amorphous cellulose is also degraded resulting in an increase of cellulose crystallinity (Bhuiyan and Hirai 2000; 2001; 2005; Wikberg and Maunu 2004; Boonstra and Tjeerdsma 2006). In lignin there is a cleavage of $\beta-\mathrm{O}-4$ linkages and a reduction of methoxyl content leading to a more condensed structure (Wikberg and Maunu 2004). 
With heat treatment the colour of wood is modified acquiring a darker tonality which is often justified by the formation of coloured degradation products from hemicelluloses (Sehistedt-Persson 2003; Sundqvist 2004) and to extractives that seem to participate in the colour formation of hydrothermally treated wood. (McDonald et al. 1997; Sundqvist and Morén 2002). The formation of oxidation products such as quinones is also referred as the reason for colour change (Tjeerdsma et al. 1998; Mitsui et al. 2001; Bekhta and Niemz 2003). Sehistedt-Persson (2003) also suggested that the change in colour resulting from hemicellulose degradation might be due to hydrolysis by a reaction similar to a Maillard reaction which is a well-known process in the food industry.

Colour is a very important wood property for the final consumer and, in some cases, it is the determining factor for the selection of a specific wood since the visual decorative point of view is often prevailing. In species with pale coloured wood which are usually considered less appellative, the darkening would be an important advantage of the heat treatment giving the wood a "tropical flavour" that is valued in many countries.

The colour of treated wood is also important because it can be used to predict wood properties such as mechanical resistance (Bekhta and Niemz 2003; Johansson and Móren 2006) or for heat treated wood characterization (Patzelt et al. 2003). Most wood colour studies quantify the colour by the CIELAB method created by the Commission International de l'Éclairage with a three axes system: lightness ( $\left.\mathrm{L}^{*}\right)$ from $0 \%$ (black) and $100 \%$ (white), $a^{*}$ from green (-a) to red $(+a)$, and $b^{*}$ from blue (-b) to yellow $(+b)$. Good correlations between lightness $\left(\mathrm{L}^{*}\right)$ and treatment temperature were obtained for Pinus sylvestris (Viitaniemi et al. 1997).

In this work we studied the influence of heat treatment and specific conditions of temperature, heating medium and time on wood of two species, maritime pine (Pinus pinaster) and blue-gum eucalypt (Eucalyptus globulus). These are two important species in Southern Europe and elsewhere that are not favoured by their natural colour: pine wood is yellowish in the sapwood and reddish brown in heartwood, with a high susceptibility to light, and eucalypt wood has a monotonous light brown colour. Although the Nordic market appreciates light coloured woods, in many other markets richer wood colours are preferred which are associated to higher priced tropical woods, e.g in Portugal pinewood is darkened for production of high quality furniture. In addition to improvement of other properties, the underlying hypothesis in this work is 
that the heat induced colour variation of these woods could improve their value for high quality applications.

\section{Experimental}

Cubic samples with approximately $40 \mathrm{~mm}$ edge of pine (Pinus pinaster Aiton.) and eucalypt (Eucalyptus globulus Labill.) wood were cut from a radial board with clear faces, totalling 150 samples for each species. The samples were polished with $\mathrm{P}_{100}$ sandpaper and kept in a conditioned room at $20^{\circ} \mathrm{C}$ and $50 \%$ relative humidity until stabilization. The colour of samples was measured before the heat treatment on radial, tangential and transverse sections.

Two kinds of heat treatments were made: (a) in an oven in the presence of air and (b) in an autoclave with steam in the absence of air. The heat treatment in air was made in an electric oven, with exhaustion of the heated gases by natural convection through an opening in the oven wall for 2 to $24 \mathrm{~h}$ at $170-200^{\circ} \mathrm{C}$. The treatment started at ambient temperature with a raising heat time of about one hour. Four replicates were used for each treatment conditions of time/temperature.

The steam heat treatment was made at atmospheric pressure inside an autoclave for $2-12 \mathrm{~h}$ and $190-210^{\circ} \mathrm{C}$. The autoclave had $0.5 \mathrm{~m}^{3}$ capacity and $1.0 \mathrm{~m}^{2}$ square area and it was heated by a regulated admission of a mixture of superheated steam $\left(370-380{ }^{\circ} \mathrm{C}\right)$ and saturated steam $\left(150-160^{\circ} \mathrm{C}\right)$. Temperature was controlled by auxiliary heating with a superheated steam flow in the autoclave's sleeve. Three replicates were used for each treatment conditions of time/temperature. After treatment, the samples were cooled down in a dry environment and weighted. Mass loss was determined according to:

Mass loss $(\%)=\frac{\text { Dry mass }- \text { Dry mass after treatment }}{\text { Dry mass }}$

where the dry mass corresponds to the ovendry mass of the untreated sample and the mass after treatment corresponds to the ovendry mass of the sample after the heat treatment. The moisture content of the conditioned samples before treatment was determined in a parallel sample (four replicates) by oven drying at $105^{\circ} \mathrm{C}$.

The final colour of wood was measured after stabilization in a room at $20^{\circ} \mathrm{C}$ and $50 \%$ relative humidity, in the radial, tangential and transverse sections. A colour spectrophotometer Minolta cm-3630 was used and the $0 \%$ colour was calibrated with white and $100 \%$ with black standards. The colour parameters $\mathrm{L}^{*}, \mathrm{a}^{*}$ and $\mathrm{b}^{*}$ were 
determined for untreated and treated wood by the CIELAB method, and their corresponding variation with the treatments, $\Delta \mathrm{L}^{*}, \Delta \mathrm{a}^{*}$ and $\Delta \mathrm{b}^{*}$, were calculated in percent of the initial value. Each value corresponds to the average of three (autoclave treatment) or four (oven treatment) replicates.

The variation in colour was calculated as the difference of $\mathrm{L}^{*}, \mathrm{a}^{*}$ and $\mathrm{b}^{*}$ between treated and untreated wood in percentage of the initial value, as measured in each individual sample, as follows (exemplified for $\Delta \mathrm{L}^{*}$ ):

$$
\Delta \mathrm{L}^{*}(\%)=\left(\mathrm{L}^{*}{ }_{\text {treared }}-\mathrm{L}^{*} \text { untreared }\right) / \mathrm{L}^{*} \text { untreared }
$$

The extractive content was determined by successive Soxhlet extraction of about $3 \mathrm{~g}$ of each sample using successively $150 \mathrm{ml}$ of dichloromethane, ethanol and water during 10 hours for dichloromethane and 20 hours for ethanol and water. The total content was determined by the sum of all the extracts. Lignin was determined by the Klason method. The sugars content was determined according to Tappi $249 \mathrm{~cm}-00$. The solution obtained in the lignin analysis was neutralized, derivatized by acetylation and injected in a gaseous chromatograph HP 5890A with a S2330 column and ionization flame detector. The temperatures of the injector and detector were kept at $250^{\circ} \mathrm{C}$ while the temperature of the oven initiated at $225^{\circ} \mathrm{C}$ during 1 minute, followed by an increase of $5^{\circ} \mathrm{C}$ min- 1 up to $250{ }^{\circ} \mathrm{C}$ and remaining at this temperature for 3 minutes.

\section{Results and discussion}

\section{Natural wood colour}

The colour of eucalypt and pine wood samples was determined before the heat treatments in the radial, tangential and transverse sections. Table 1 presents the CIELAB parameters $\mathrm{L}^{*}, \mathrm{a}^{*}$ and $\mathrm{b}^{*}$ for the untreated pine and eucalypt wood.

Table 1. Colour CIELAB parameters for eucalypt and pine wood in transverse, radial and tangential sections. Average of 110 samples.

\begin{tabular}{|c|c|c|c|c|c|c|c|c|c|}
\hline & \multicolumn{3}{|c|}{ Transverse } & \multicolumn{3}{|c|}{ Radial } & \multicolumn{3}{|c|}{ Tangential } \\
\hline & $\mathrm{L}^{*}$ & $a^{*}$ & $\mathrm{~b} *$ & $\mathrm{~L} *$ & $a^{*}$ & $\mathrm{~b} *$ & $\mathrm{~L} *$ & $a^{*}$ & $\mathrm{~b} *$ \\
\hline & \multicolumn{9}{|c|}{ Eucalypt } \\
\hline Average & 54.1 & 7.4 & 15.7 & 63.8 & 8.0 & 19.9 & 61.5 & 8.5 & 18.9 \\
\hline Minimum & 48.1 & 5.4 & 14.3 & 56.9 & 6.8 & 16.2 & 53.7 & 6.7 & 16.3 \\
\hline Maximum & 63.6 & 9.6 & 20.3 & 67.4 & 10.1 & 23.0 & 69.9 & 11.7 & 30.4 \\
\hline \multirow[t]{2}{*}{ Standard deviation } & 2.7 & 0.9 & 0.9 & 1.9 & 0.7 & 0.9 & 2.7 & 1.1 & 1.4 \\
\hline & \multicolumn{9}{|c|}{ Pine } \\
\hline Average & 76.1 & 6.9 & 24.1 & 74.3 & 7.6 & 23.3 & 67.3 & 7.2 & 16.3 \\
\hline Minimum & 57.7 & 5.5 & 17.8 & 56.9 & 5.3 & 17.4 & 48.1 & 5.8 & 13.8 \\
\hline Maximum & 80.4 & 9.1 & 27.6 & 78.7 & 11.4 & 28.5 & 72.0 & 8.7 & 19.6 \\
\hline Standard deviation & 4.4 & 0.6 & 2.1 & 4.6 & 1.1 & 3.0 & 5.1 & 0.6 & 1.2 \\
\hline
\end{tabular}


The eucalypt wood samples showed a homogeneous colour that according to the chroma coordinates $\mathrm{a}^{*}$ and $\mathrm{b}^{*}$ is a combination of red $\left(\mathrm{a}^{*}\right)$ and yellow $\left(\mathrm{b}^{*}\right)$. The eucalypt wood surfaces showed some differences between sections. On average, transverse sections were darker than tangential and radial sections: lightness $\left(\mathrm{L}^{*}\right)$ was on average $54.1 \%$ in the transverse section as compared with $63.8 \%$ and $61.5 \%$ for radial and tangential sections. The transverse section showed lower values for $\mathrm{a}^{*}$ and $\mathrm{b}^{*}$ (7.4 and 15.7) as compared with the tangential (8.5 and 18.9) and radial (8.0 and 19.9) sections but the differences between sections were not statistically significant. The between sample variation of the colour coordinates was also small as given by the low values for the standard deviation.

The surface of the pine wood samples was more heterogeneous in colour than that of eucalypt wood samples, with darker zones corresponding to latewood, and clearer zones corresponding to earlywood, thereby reflecting their differences in wood anatomy and ring structure, which resulted into a higher between sample variation. On average lightness $\left(\mathrm{L}^{*}\right)$ was lower for the tangential section $(67.3 \%)$ in comparison with the radial $(74.3 \%)$ and transverse $(76.1 \%)$ sections, although the differences between sections were not statistically significant.

Pine wood colour was a combination of red $\left(a^{*}\right)$ and yellow $\left(b^{*}\right)$. On average $a^{*}$ was higher on radial (7.6), followed by tangential (7.2) and transverse (6.9) sections but without significant differences between sections. The $b^{*}$ value was higher on the transverse (24.1) and radial (23.3) sections in relation to the tangential (16.3) section.

\section{Heat treated wood colour}

Darkening with the heat treatment was clearly visible, increasing with treatment time and temperature which is in agreement with earlier findings (Mitsui et al. 2001, 2003; Militz 2002; Bekhta and Niemz 2003).

Eucalypt heat treated wood revealed a uniform colour that darkened with the increase of treatment severity. The colour shown by the pine heat treated wood was less uniform because of the increased contrast between earlywood and latewood, and therefore the colour of samples depended on the earlywood/latewood ratio on the sample surface. Also in some cases there was formation of darker spots at the surface due to the exudation of some resin. 
After the heat treatment, the colour on the radial, tangential and transverse sections was measured and the difference of $\mathrm{L}^{*}, \mathrm{a}^{*}$ and $\mathrm{b}^{*}$ in percentage between treated and untreated wood was determined as $\Delta \mathrm{L}^{*}(\%), \Delta \mathrm{a}^{*}(\%)$ and $\Delta \mathrm{b}^{*}(\%)$. respectively.

\section{Treatment with hot air}

The changes in lightness $\left(\mathrm{L}^{*}\right)$ and the chroma parameters $\left(\mathrm{a}^{*}\right.$ and $\left.\mathrm{b}^{*}\right)$ of oven heat treated pine and eucalypt wood are presented on Table 2.

Table 2 Variation in $\left(\mathrm{L}^{*}, \mathrm{a}^{*}\right.$ and $\left.\mathrm{b}^{*}\right)$ of oven heat treated pine and eucalypt wood

\begin{tabular}{|c|c|c|c|c|c|c|c|c|c|c|c|}
\hline & \multirow{2}{*}{$\begin{array}{c}\text { Temperature } \\
\left({ }^{\circ} \mathrm{C}\right)\end{array}$} & \multirow{2}{*}{$\begin{array}{l}\text { Treatment } \\
\text { Time (hr) }\end{array}$} & \multicolumn{3}{|c|}{$\Delta \mathrm{L}^{*}(\%)$} & \multicolumn{3}{|c|}{$\Delta \mathrm{a}^{*}(\%)$} & \multicolumn{3}{|c|}{$\Delta \mathrm{b}^{*}(\%)$} \\
\hline & & & Tranv & Radial & Tang & Tranv & Radial & Tang & Tranv & Radial & Tang \\
\hline \multirow{15}{*}{ Eucalypt } & \multirow{4}{*}{$170^{\circ} \mathrm{C}$} & 2 & -17.1 & -10.3 & -18.0 & 9.0 & 23.7 & 16.1 & -8.6 & -1.5 & -5.6 \\
\hline & & 6 & -27.9 & -25.0 & -35.0 & 7.8 & 17.3 & 10.9 & -15.5 & -9.1 & -19.7 \\
\hline & & 12 & -39.6 & -38.4 & -44.4 & -10.1 & 11.7 & -9.3 & -33.6 & -24.2 & -32.0 \\
\hline & & 24 & -45.5 & -50.1 & -50.8 & -8.4 & -5.6 & -4.0 & -35.1 & -40.4 & -37.4 \\
\hline & \multirow{4}{*}{$180^{\circ} \mathrm{C}$} & 2 & -19.6 & -17.3 & -19.4 & 13.3 & 22.2 & 8.0 & -0.2 & -1.7 & -1.2 \\
\hline & & 6 & -38.7 & -38.3 & -43.3 & -18.9 & 12.4 & -1.9 & -37.4 & -19.6 & -33.3 \\
\hline & & 12 & -44.8 & -45.6 & -50.2 & -16.4 & 8.1 & -17.8 & -39.3 & -28.2 & -44.8 \\
\hline & & 24 & -51.5 & -51.7 & -55.6 & -28.3 & 1.1 & -35.0 & -54.1 & -42.1 & -69.5 \\
\hline & \multirow{4}{*}{$190^{\circ} \mathrm{C}$} & 2 & -33.9 & -34.2 & -42.3 & 2.8 & 21.5 & 2.9 & -23.5 & -13.6 & -33.7 \\
\hline & & 6 & -45.6 & -49.3 & -51.2 & -26.2 & 1.2 & -22.4 & -45.6 & -37.3 & -56.9 \\
\hline & & 12 & -50.2 & -54.4 & -54.3 & -40.5 & -18.6 & -41.2 & -64.2 & -59.9 & -65.7 \\
\hline & & 24 & -50.8 & -56.3 & -55.3 & -29.2 & -37.0 & -40.8 & -58.4 & -70.1 & -72.2 \\
\hline & \multirow{3}{*}{$200^{\circ} \mathrm{C}$} & 2 & -38.9 & -36.6 & -43.6 & -8.0 & 16.9 & -7.6 & -31.2 & -18.8 & -37.1 \\
\hline & & 6 & -50.5 & -51.6 & -56.0 & -49.6 & -13.5 & -38.7 & -67.9 & -46.7 & -69.8 \\
\hline & & 12 & -52.7 & -56.2 & -59.2 & -45.5 & -28.6 & -60.2 & -70.8 & -66.3 & -85.6 \\
\hline \multirow{15}{*}{ Pine } & \multirow{15}{*}{$170^{\circ} \mathrm{C}$} & 2 & -9.4 & -10.5 & -12.8 & -12.4 & 22.8 & 26.5 & 19.5 & 12.2 & 22.7 \\
\hline & & 6 & -19.0 & -17.7 & -20.7 & -5.9 & 48.3 & 41.7 & 25.1 & 14.7 & 27.1 \\
\hline & & 12 & -25.2 & -28.7 & -52.4 & -7.9 & 83.3 & 20.6 & 31.5 & 14.7 & -21.6 \\
\hline & & 24 & -32.1 & -44.7 & -45.3 & 11.5 & 87.2 & 71.5 & 31.8 & -6.5 & -8.0 \\
\hline & & & -15.2 & -14.1 & -19.4 & -0.7 & 27.7 & 55.5 & 24.9 & 12.2 & 23.7 \\
\hline & & & -24.3 & -34.7 & -32.8 & 7.4 & 83.2 & 72.9 & 38.3 & 11.1 & 19.2 \\
\hline & & & -36.1 & -44.3 & -47.0 & 18.7 & 77.2 & 76.6 & 27.8 & -6.4 & -8.7 \\
\hline & & 24 & -40.5 & -52.5 & -52.1 & 32.1 & 66.9 & 37.8 & 29.1 & -27.2 & -35.0 \\
\hline & & 2 & -19.4 & -23.9 & -25.7 & -6.4 & 70.3 & 66.2 & 27.1 & 21.9 & 26.8 \\
\hline & & & -32.8 & -43.1 & -38.1 & 14.1 & 79.4 & 72.5 & 33.4 & -4.4 & 15.9 \\
\hline & & 12 & -45.4 & -57.4 & -56.3 & 12.3 & 52.4 & 39.0 & -0.9 & -43.8 & -45.8 \\
\hline & & 24 & -49.4 & -58.5 & -58.8 & 8.1 & 30.8 & 14.6 & -20.7 & -53.2 & -57.8 \\
\hline & & 2 & -28.4 & -35.3 & -33.9 & -0.8 & 87.4 & 64.8 & 31.2 & 2.6 & 12.2 \\
\hline & & 6 & -44.6 & -52.1 & -54.0 & 9.7 & 68.6 & 40.3 & 3.1 & -28.2 & -38.1 \\
\hline & & 12 & -52.9 & -59.5 & -60.4 & 4.9 & 38.8 & 3.3 & -25.2 & -49.4 & -63.4 \\
\hline
\end{tabular}

Lightness of heat treated pine and eucalypt wood decreased with treatment time and temperature. For instance, pine wood lightness in transverse section decreased $9.4 \%$ and $28.4 \%$ with two hours of treatment, at $170^{\circ} \mathrm{C}$ and $200^{\circ} \mathrm{C}$, respectively (Table 2 ). The maximum reduction $(52.9 \%)$ was obtained with 12 hours at $200^{\circ} \mathrm{C}$. Similar results were obtained by Bekhta and Niemz (2003) with spruce wood, who reported a 73\% decrease on lightness for a treatment at $200{ }^{\circ} \mathrm{C}$ for $24 \mathrm{~h}$.

Lightness reduction for the less intensive $2 \mathrm{~h}$ treatment for eucalypt wood was $17.2 \%$ and $38.9 \%$ at $170^{\circ} \mathrm{C}$ and $200^{\circ} \mathrm{C}$, respectively. With increasing time and temperature eucalypt wood lightness reduction reached $52.7 \%$ for $12 \mathrm{~h}$ at $200^{\circ} \mathrm{C}$ (Table 2). 
The reduction on lightness for heat treated pine wood was similar for radial and tangential sections reaching at the most $59.5 \%$ and $60.4 \%$, and slightly higher than for transverse section $(52.9 \%)$ probably due to the initial darker colour of this section (Table 2).

For eucalypt wood, lightness decreased more in tangential section (59.2\%), compared with radial (56.2\%) and transverse (52.7\%) sections. The differences between sections in eucalypt wood were small, because the colour of tangential and transverse sections is uniform despite of the tonality difference due to growth layers visible in transverse section (Table 2).

The $\mathrm{a}^{*}$ parameter for pine wood presented a high variation in transverse section, decreasing initially, increasing afterwards and decreasing again for more severe treatments. In radial and tangential sections $a^{*}$ increased for less intense treatments reaching a $87 \%$ and $72 \%$ increase for wood treated at $170^{\circ} \mathrm{C}$ for 24 hours, but decreasing with the increase in treatment severity. The $b^{*}$ increased initially and decreased afterwards for all the sections (Table 2).

The behaviour of the chroma coordinates differed for eucalypt wood. Coordinate $\mathrm{a}^{*}$ increased slightly for less intensive treatments and decreased afterwards reaching $46 \%,-29 \%$ and $-60 \%$ for wood treated at $200^{\circ} \mathrm{C}$ during $12 \mathrm{~h}$.

Coordinate $b^{*}$ decreased with treatment time for all temperatures and sections, with a maximum decrease of $-71 \%,-66 \%$ and $-86 \%$ for transverse, radial and tangential sections, respectively (Table 2).

Figure 1 presents the colour spectrum of the radial section for untreated wood and for oven heat treated pine and eucalypt wood with two treatments, an intermediary treatment at $180^{\circ} \mathrm{C}$ during $8 \mathrm{~h}$ and a more severe one at $190^{\circ} \mathrm{C}$ during $24 \mathrm{~h}$, corresponding to mass losses of $3.2 \%$ and $7.6 \%$ for pine wood and $3.1 \%$ and $9.7 \%$ for eucalypt wood, respectively. 


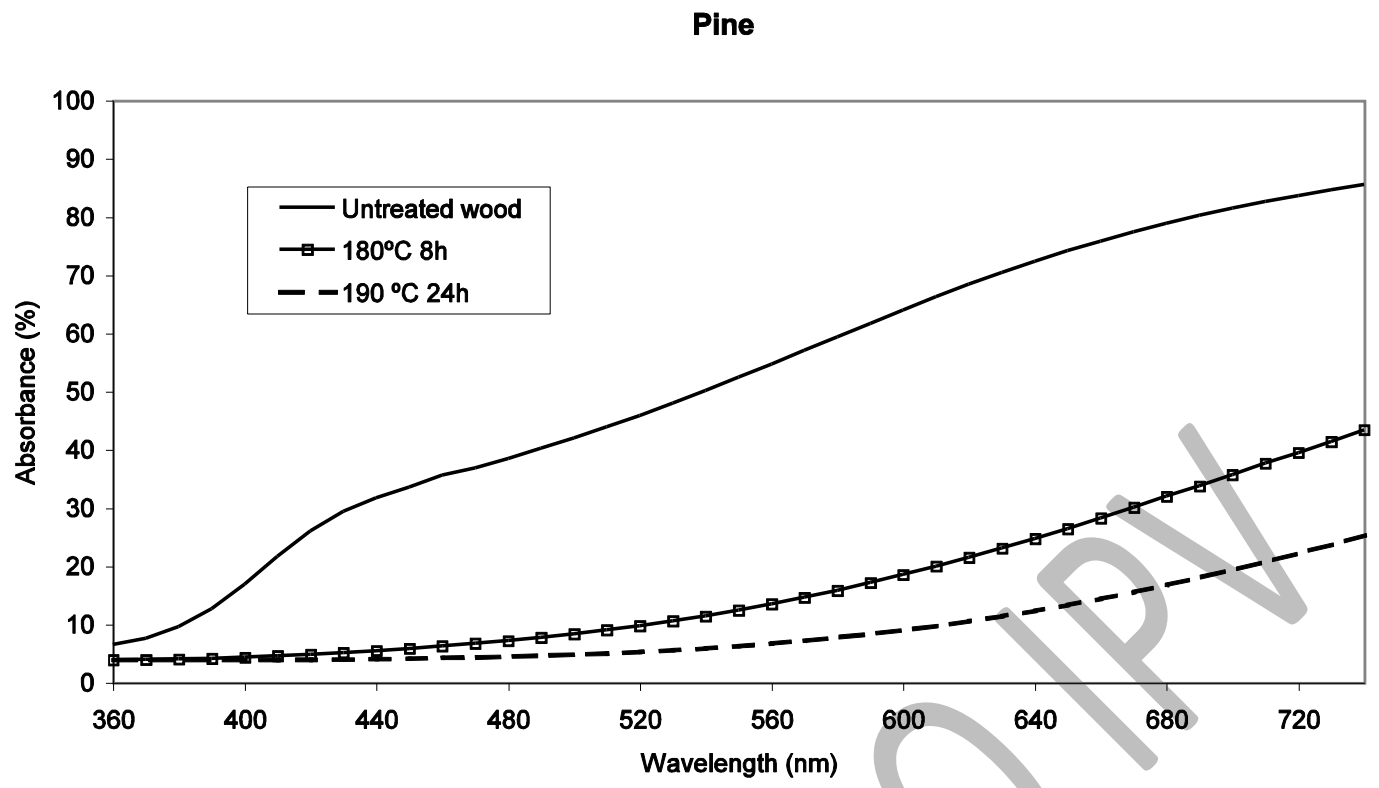

\section{Eucalypt}

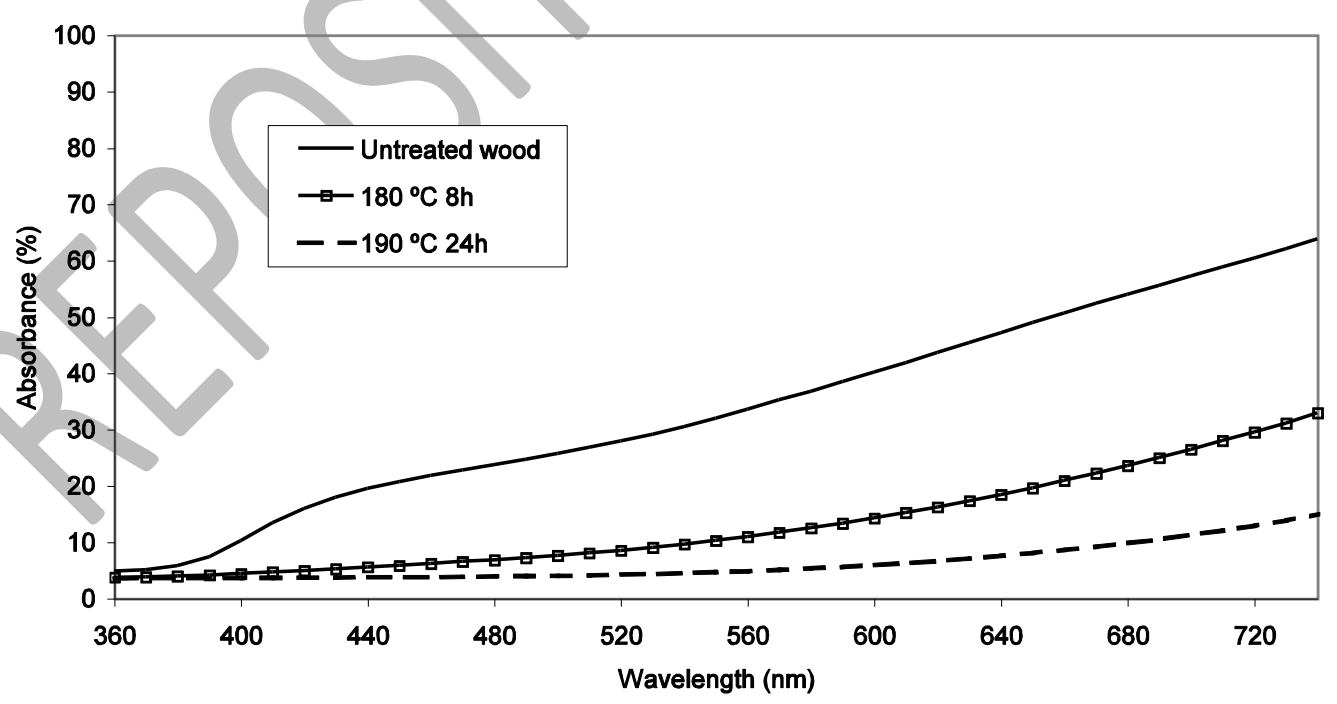

Figure 1. Colour spectrum for untreated wood and for oven heat treated pine and eucalypt wood in the radial section.

The difference of the wood colour spectrum before and after the treatment is striking, with a decreased absorbance throughout the entire spectrum for the heat treated 
samples. The absorbance in the violet region $(390-455 \mathrm{~nm})$ is practically nil for the woods treated at $190^{\circ} \mathrm{C}$ during $24 \mathrm{~h}$. The absorbance increases with wavelength with a maximum in the red region $(622-780 \mathrm{~nm})$. The shoulder around $420 \mathrm{~nm}$ in the untreated wood spectrum disappears with the heat treatment.

In pine wood the absorbance decreased more in the radial section, and no difference was observed between tangential and transverse sections. In eucalypt wood the reduction was higher in the tangential section, followed by the radial and transverse sections.

The relation between chemical composition and lightness decrease for oven heat treated pine wood is presented on Figure 2.

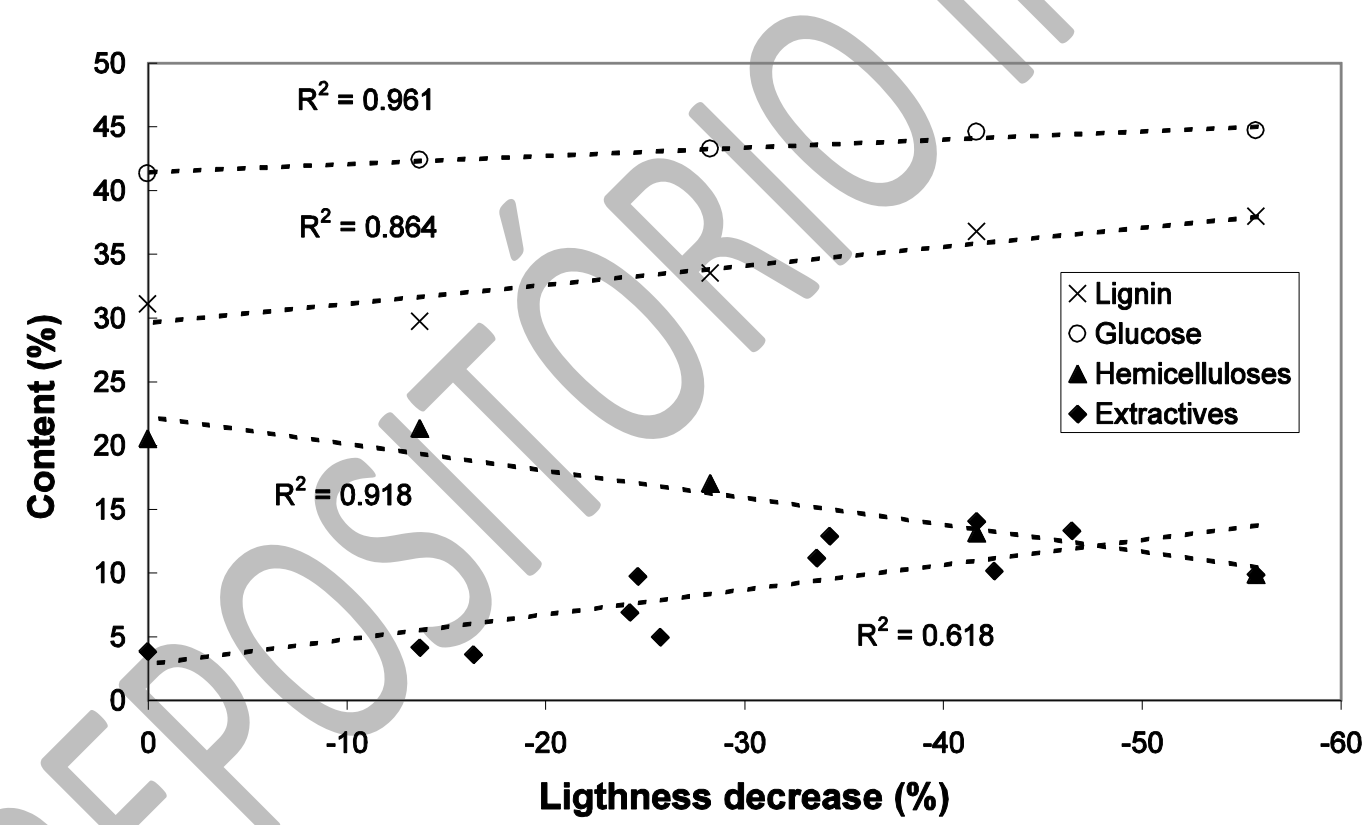

Figure 2. Relation between chemical composition and lightness decrease for oven heat treated pine wood

The results show that there is a strong correlation between lightness decrease and chemical composition. The stronger correlation was observed for glucose content with a determination coefficient $\left(\mathrm{R}^{2}\right)$ for linear regression of 0.96 , followed by hemicelluloses $\left(\mathrm{R}^{2}=0.92\right)$. These results are in accordance with several authors who attribute colour change with heat treatment to the formation of coloured degradation products from hemicelluloses (Sehistedt-Persson 2003; Sundqvist 2004). 
The correlations for lignin and extractive content were poorer with $\mathrm{R}^{2}=0.86$ and $\mathrm{R}^{2}=0.62$, respectively. Some authors referred that extractives seem to participate in the colour formation of hydrothermally treated wood (McDonald et al. 1997; Sundqvist and Morén 2002) while others reason that colour change might be due to the formation of oxidation products such as quinones (Tjeerdsma et al. 1998; Mitsui et al. 2001; Bekhta and Niemz 2003). The explanation for the lower determination coefficient for extractives might be because most of the chomophoric substances can not be extracted due to their high molecular mass and degree of cross-linking, as referred by Mayer et al. (2006).

\section{Steam heat treatment}

Pine and eucalypt wood became darker with steam heat treatment similarly to what happened in the treatment with hot air. In identical conditions the lightness decrease was smaller for the steam heat treatment. For example for eucalypt wood treated at $190^{\circ} \mathrm{C}$ for 6 hours the decrease in ligtness was 43.8 and $45.6 \%$ for autoclave and oven treatment.

The changes in lightness $\left(\mathrm{L}^{*}\right)$ and on the chroma parameters $\left(\mathrm{a}^{*}\right.$ and $\left.\mathrm{b}^{*}\right)$ of autoclave heat treated pine and eucalypt wood are presented on Table 3.

Table 3 Variation in $\left(\mathrm{L}^{*}, \mathrm{a}^{*}\right.$ and $\left.\mathrm{b}^{*}\right)$ of autoclave heat treated pine and eucalypt wood

\begin{tabular}{|c|c|c|c|c|c|c|c|c|c|c|c|}
\hline & \multirow{2}{*}{$\begin{array}{c}\text { Temperature } \\
\left({ }^{\circ} \mathrm{C}\right)\end{array}$} & \multirow{2}{*}{$\begin{array}{l}\text { Treatment } \\
\text { Time (hr) }\end{array}$} & \multicolumn{3}{|c|}{$\Delta \mathrm{L}^{*}(\%)$} & \multicolumn{3}{|c|}{$\Delta \mathrm{a}^{*}(\%)$} & \multicolumn{3}{|c|}{$\Delta b^{*}(\%)$} \\
\hline & & & Tranv & Radial & Tang & Tranv & Radial & Tang & Tranv & Radial & Tang \\
\hline \multirow{9}{*}{ Eucalypt } & & & -41.7 & -41.6 & -36.6 & -4.9 & 10.2 & 10.5 & -38.4 & 10.2 & -22.7 \\
\hline & & & -43.8 & -47.0 & -45.5 & -6.2 & 2.8 & 6.6 & -37.7 & 2.8 & -33.4 \\
\hline & & 12 & -44.0 & -46.0 & -44.8 & -14.5 & -4.0 & -4.0 & -45.7 & -4.0 & -36.5 \\
\hline & & 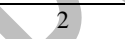 & -36.5 & -36.3 & -37.2 & 3.5 & 9.7 & 16.1 & -25.9 & -24.6 & -22.2 \\
\hline & & & -50.7 & -51.6 & -52.7 & -16.1 & -13.0 & -7.7 & -50.3 & -52.6 & -46.6 \\
\hline & & 12 & -51.5 & -54.4 & -54.1 & -39.0 & -23.1 & -26.1 & -62.9 & -58.6 & -58.4 \\
\hline & & 2 & -49.6 & -50.4 & -49.0 & -21.7 & -7.5 & -22.5 & -43.9 & -43.7 & -45.8 \\
\hline & & 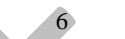 & -53.1 & -54.7 & -55.8 & -42.5 & -33.9 & -39.0 & -64.8 & -62.9 & -64.4 \\
\hline & & 12 & -54.5 & -56.8 & -56.7 & -53.2 & -38.0 & -38.3 & -72.7 & -67.8 & -63.5 \\
\hline \multirow{9}{*}{ Pine } & & 2 & -19.2 & -38.6 & -24.4 & 82.4 & 33.5 & 52.3 & 42.2 & -9.7 & 13.1 \\
\hline & & 6 & -28.1 & -41.2 & -34.6 & 63.1 & 33.6 & 94.0 & 26.7 & -12.4 & 19.1 \\
\hline & & 12 & -29.9 & -40.3 & -34.8 & 70.3 & 30.9 & 78.6 & 32.4 & -13.6 & 5.7 \\
\hline & & 2 & -20.3 & -37.6 & -30.3 & 51.6 & 25.4 & 37.4 & 33.7 & -6.3 & 2.6 \\
\hline & $200^{\circ} \mathrm{C}$ & 6 & -30.7 & -43.4 & -37.3 & 64.1 & 42.0 & 62.9 & 21.4 & -11.1 & -0.5 \\
\hline & & 12 & -34.1 & -45.2 & -39.8 & 59.9 & 43.1 & 54.5 & 18.3 & -13.6 & -5.0 \\
\hline & & 2 & -34.6 & -44.8 & -40.0 & 50.7 & 48.0 & 83.0 & 11.0 & -16.8 & 0.9 \\
\hline & $210^{\circ} \mathrm{C}$ & 6 & -39.5 & -52.9 & -47.6 & 66.6 & 40.4 & 54.6 & 9.8 & -30.7 & -13.5 \\
\hline & & 12 & -40.8 & -50.9 & -47.5 & 56.2 & 44.3 & 49.6 & 9.0 & -21.9 & -17.7 \\
\hline
\end{tabular}

The decrease in lightness of pine wood $\left(\mathrm{L}^{*}\right)$ was higher in the radial and tangential sections, with a maximum decrease of $51 \%, 48 \%$ and $41 \%$, respectively in radial, tangential and transverse sections for wood treated at $210^{\circ} \mathrm{C}$ during 12 hours 
(Table 3). A similar decrease in lightness (53\%) was reported by Brischke et al. (2007) for spruce wood.

For eucalypt wood the lightness reduction was high even for the less intensive steam heat treatment, $2 \mathrm{~h}$ at $190^{\circ} \mathrm{C}$, with a reduction of lightness of $42 \%, 42 \%$ and $37 \%$ in transverse, radial and tangential sections, much above that obtained for the heat treatment in air. With increasing treatment time and temperature, the decrease in lightness became similar to that obtained with the heat treatment in air. For instance the decrease was about 52.7 and $51.5 \%$ for oven and autoclave treatment for wood treated at $200^{\circ} \mathrm{C}$ during 12 hours (Table 2 and 3 ).

Heat treated eucalypt wood was darker than heat treated pine wood for both treatments, and showed a colour similar to the majority of commercial tropical woods.

\section{Colour changes with mass loss}

The colour variation was related to the mass loss that occurred with both heat treatments. Figure 3 reports the variation in lightness $\left(\mathrm{L}^{*}\right)$ versus mass loss with heating. Lightness of heat treated pine and eucalypt woods decreased with mass loss for both treatments.
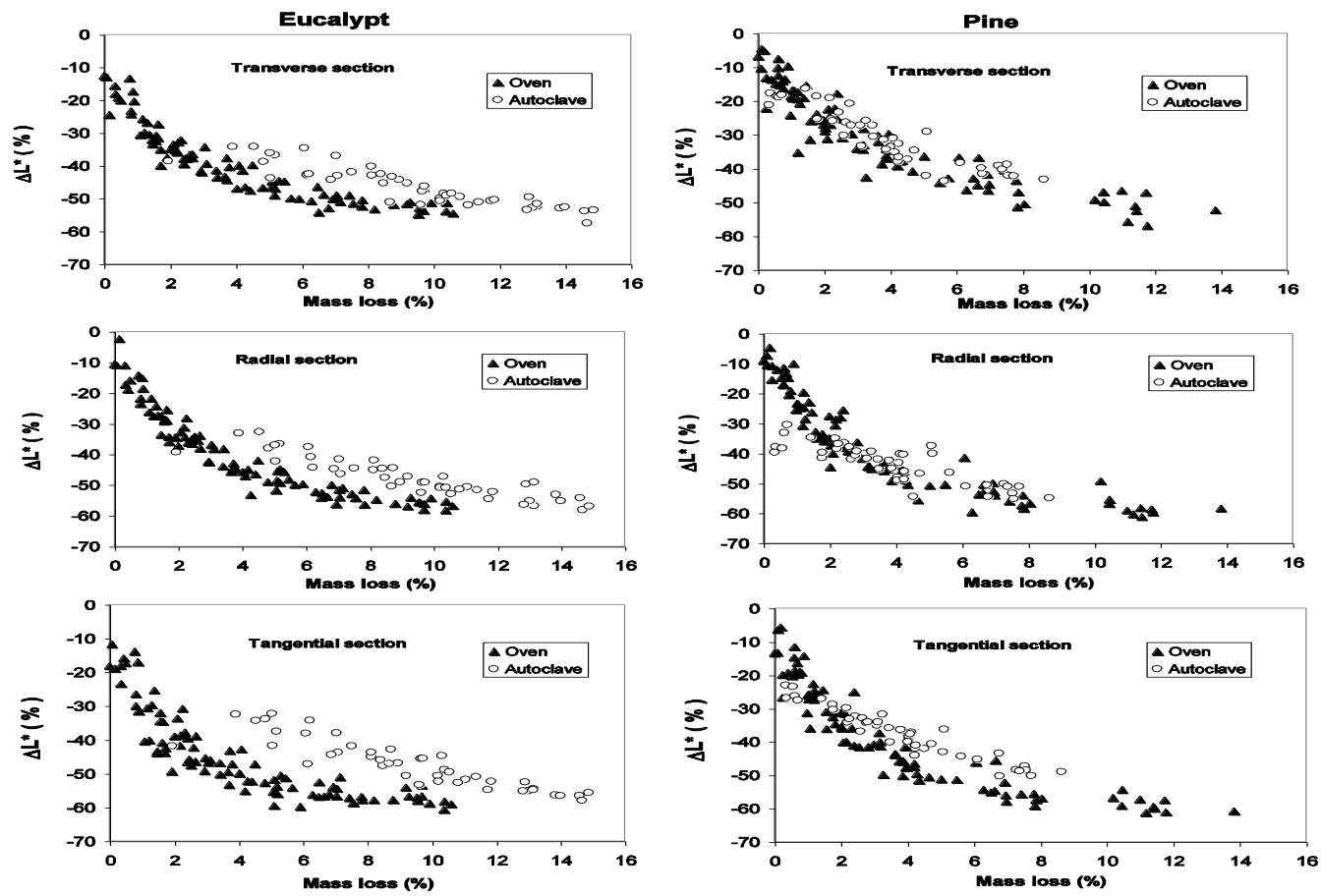

Figure 3. Wood lightness $\left(L^{*}\right)$ versus mass loss with steam (autoclave) and air (oven) heat treatment of eucalypt and pine woods measured in the transverse, radial and tangential sections. 
With air the rate of lightness reduction was higher until about $4 \%$ mass loss, when the heat treated wood became about $50 \%$ darker than the original wood, after which it tended for stabilization at a minimum value, which is in agreement with earlier findings by Mitsui et al. (2003) and Bekhta and Niemz (2003). For the same mass loss there were no significant differences between pine and eucalypt wood. In relation to differences between sections in the lightness reduction it was found that in pine wood it was slightly higher in the transverse section while in eucalypt wood lightness decreased slightly more in the tangential section although the differences between sections were very small.

For the steam heating, the lightness decrease was approximately linear with mass loss. The decrease was higher in the radial section of pine wood, while in eucalypt wood it was approximately similar for all sections.

Comparing steam and air heat treatments at the same mass loss, the lightness reduction was higher in air especially for eucalypt wood. Similar results of oxidation reactions leading to darker compounds were also reported by Mitsui et al. (2003) with heat treated spruce wood in air and in an inert nitrogen atmosphere.

The changes in $\mathrm{a}^{*}$ versus mass loss are presented in Figure 4. For the air heat treated pine wood, there was a striking initial increase, until about 3\% mass loss in radial and tangential sections, exceeding $100 \%$ and decreasing afterwards, while in the transverse section the increase was small until about $4 \%$ mass loss and followed by a smooth reduction. These results are in accordance with Bekhta and Niemz (2003) who reported an initial increase in $a^{*}$ from 5.5 to about 10.5 followed by a small decrease for heat treated spruce wood.

For the air heat treated eucalypt wood, a* increased a little until about $1 \%$ mass loss reaching about $35 \%$ in radial and transverse sections and $20 \%$ in tangential, followed by a linear decrease for all sections. The reduction was higher in tangential section of about $80 \%$ for a $10 \%$ mass loss $(60 \%$ in transverse and $40 \%$ in radial sections).

The behaviour of $a^{*}$ variation for steam heat treated pine and eucalypt wood seems to be similar to air heat treatment, but with a higher dispersion. For pine wood, $\mathrm{a}^{*}$ increased until about 3-4\% for all sections decreasing with the increase of mass loss, but in the transverse section values are considerably higher than for air heat treated wood. For eucalypt wood, a* decreased linearly with mass loss similarly to air heat treated wood but with slightly higher values. 

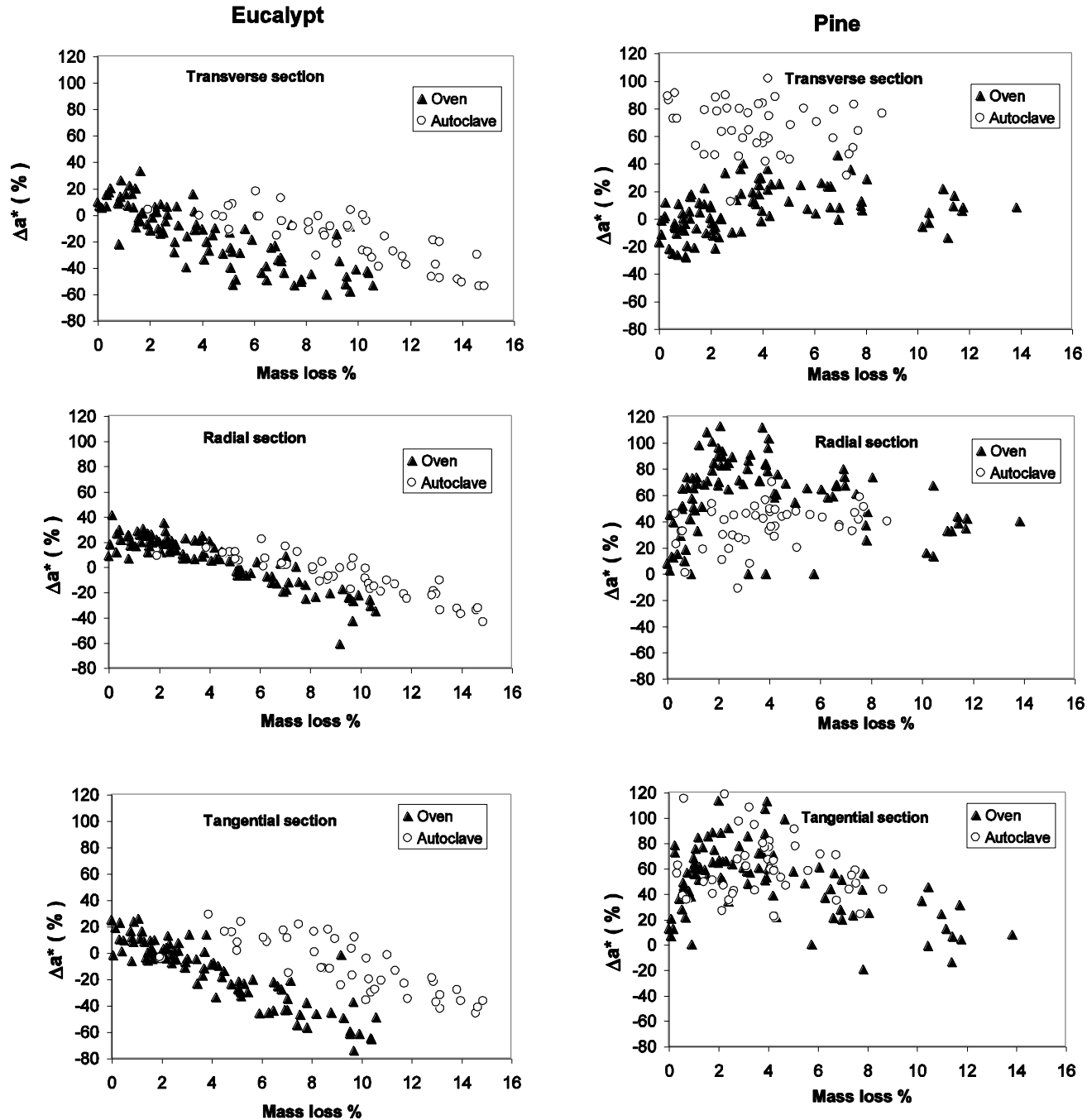

Figure 4. Variation of $a^{*}$ with mass loss by steam and air heat treatment of pine and eucalypt wood.

Figure 5 presents $\Delta \mathrm{b}^{*}$ versus mass loss with air and steam heat treatment. For pine wood the results for the air and steam heat treatments were similar: $b^{*}$ increased until about $2 \%$ mass loss, and decreased for higher mass losses, reaching approximately $60 \%$ for $12 \%$ mass loss without significant differences between the three sections. Bekhta and Niemz (2003) reported similar results with spruce wood. 

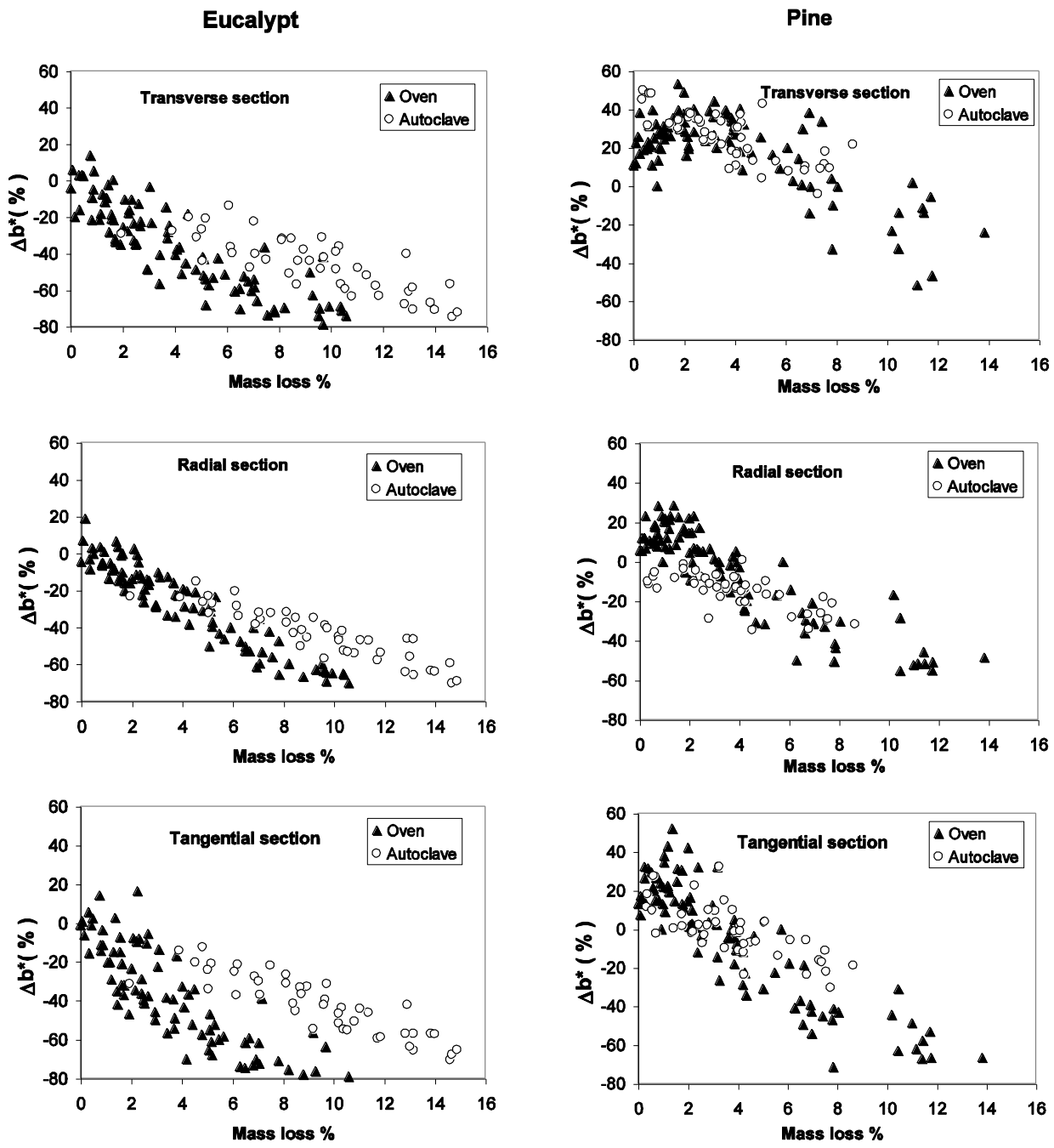

Figure 5. Variation of $b^{*}$ with mass loss by steam and air heat treatment of pine and eucalypt wood.

For eucalypt wood, $b^{*}$ decreased linearly with mass loss, but at a slower rate for the steam treatment. For $4 \%$ mass loss, in the air treatment the reduction was approximately $50 \%, 40 \%$ and $35 \%$ respectively for the tangential, transverse and radial sections and with steam heating, the $\mathrm{b}^{*}$ decreased less, reaching $25 \%, 20 \%$ and $25 \%$ respectively.

\section{CONCLUSIONS}

Heat treatments in presence and absence of air darkened the pine and eucalypt woods and in general decreased the red $\left(a^{*}\right)$ and yellow $\left(b^{*}\right)$ colour components. This colour change is advantageous for species of unappealing wood colour like pine and eucalypt. Therefore, the heat treatment showed an interesting potential to improve the 
wood quality as regards colour and its value for solid timber products from pine and eucalypt.

Noticeable colour changes could already be obtained for small mass losses of 2$4 \%$ but the effect depended on the extent of treatment and was related to chemical composition of the heat treated woods. In air the colour alteration was higher and faster than in steam. The heat treated woods maintained surface characteristics resulting from their anatomical structure, namely distinction of earlywood/latewood in pinewood and some differences between transverse and radial/tangential sections.

\section{REFERENCES}

Bekhta P, Niemz P (2003) Effect of high temperature on the change in color, dimensional stability and mechanical properties of spruce wood. Holzforschung 57: 539-546

Bengtsson C, Jermer J, Brem F (2002) Bending strength of heat-treated spruce and pine timber. In: International Research Group Wood Pre, Section 4-Processes, No IRG/WP 02-40242

Bhuiyan T, Hirai N (2000) Changes of crystallinity in wood cellulose by heat treatment under dried and moist conditions. J Wood Sci 46: 431-436

Bhuiyan T, Hirai N (2001) Effect of intermittent heat treatment on crystallinity in wood cellulose. J Wood Sci 47: 336-341

Bhuiyan T, Hirai N (2005) Study of crystalline behaviour of heat-treated wood cellulose during treatments in water. J Wood Sci 51: 42-47

Boonstra M, Tjeerdsma B (2006) Chemical analysis of heat treated softwoods. Holz Roh-Werkst, Online first, DOI: $10.1007 / \mathrm{s} 00107-005-0078-4$

Bourgois J, Bartholin M, Guyonnet R (1989) Thermal treatment of wood: analysis of the obtained product. Wood Sci Technol 23: 303-310

Bourgois J, Guyonnet R (1988) Characterisation and analysis of torrefied wood. Wood Sci Technol 22: $143-155$

Brischke C, Welzbacher C, Brandt K, Rapp A (2007) Quality control of thermally modified timber: Interrelationship between heat treatment intensities and CIE L*a*b* color data on homogenized wood samples. Holzforschung 61:19-22

Burmester A. (1973) Investigation on the dimensional stabilization of wood, Bundesanstalt für Materialprüfung, Berlin-Dahlem: 50-56

D’Jakonov K, Konepleva T (1967) Moisture absorption by Scots Pine wood after heat treatment. Lesn. Z., Arhangel'sk 10(1):112-114

Dirol D, Guyonnet R (1993) Durability by rectification process. In: International Research Group Wood Pre, Section 4-Processes, No IRG/WP 93-40015

Epmeier H, Bengtsson C, Westin M (2001) Effect of acetylation and heat treatment on dimensional stability and MOE of spruce timber, In: Proceedings for the first conference of the European society for wood mechanics April 19-21 2001, Lausanne, Switzerland

Esteves B, Velez Marques A, Domingos I, Pereira, H (2007) Influence of steam heating on the properties of pine (Pinus pinaster) and eucalypt (Eucalyptus globulus) wood. Wood Sci Technol. 41:193-207. DOI : 10.1007/s00226-006-0099-0 
Fengel D (1966) On the changes of the wood and its components within the temperature range up to 200 ${ }^{\circ} \mathrm{C}$ - Part 1 Holz Roh-Werkst 24: 9-14

Giebeler E (1983) Dimensionsstabilisierung von Holz durch eine Feuchte/Wärme/Druck-Behandlung. Holz Roh-Werkst 41: 87-94

Gosselink R, Krosse A, Van der Putten J, Van der Kolk J, Klerk-Engels B, Dam J (2004) Wood preservation by low-temperature carbonisation, Ind Crops Prod 19: 3-12

Hakkou M, Pétrissans M, Gérardin P, Zoulalian A (2006) Investigation of the reasons for fungal durability of heat-treated beech wood. Polym Degrad Stab 91: 393-397

Hillis W (1984) High temperature and chemical effects on wood stability. Wood Sci Technol 18: 281-293

Jämsä S, Viitaniemi P (2001) Heat treatment of wood - Better durability without chemicals. In: Proceedings of special seminar held in Antibes, France

Johansson D, Morén T (2006) The potential of colour measurement for strength prediction of thermally treated wood. Holz Roh-Werkst 64: 104-110

Kamdem D, Pizzi A, Jermannaud A (2002) Durability of heat treated wood Holz Roh-Werkst 60: 1-6

Kim G, Yun K, Kim J (1998) Effect of heat treatment on the decay resistance and the bending properties of radiata pine sapwood. Material und Organismen 32 (2): 101-108

Kollmann F, Fengel D (1965) Changes in the chemical composition of wood by thermal treatment. Holz Roh-Werkst 12: 461-468

Kollmann F, Schneider A (1963) On the sorption behaviour of heat stabilized wood. Holz Roh-Werkst 21 (3): 77-85

Kubojima Y, Okano T, Ohta M (2000) Bending strength of heat-treated wood. J Wood Sci 46: 8-15

Mayer I, Koch G, Puls J (2006) Topochemical investigations of wood extractives and their influence on colour changes in American black cherry (Prunus serotina Borkh.). Holzforschung 60: 589-594

McDonald A, Fernandez M, Kreber B (1997) Chemical and UV-VIS spectroscopic study on kiln brown stain formation in Radiata pine. $9^{\text {th }}$ International Symposium of Wood and Pulping Chemistry, Montreal, Canada $70: 1-5$

Metsä-Kortelainen S, Antikainen T, Viitaniemi P (2006) The water absorption of sapwood and heartwood of Scots pine and Norway spruce heat-treated at $170^{\circ} \mathrm{C}, 190^{\circ} \mathrm{C}, 210^{\circ} \mathrm{C}$ and $230^{\circ} \mathrm{C}$. Holz Roh-Werkst 64(3):192-197

Militz H (2002) Thermal treatment of wood: European Processes and their background. In: International Research Group Wood Pre, Section 4-Processes, N IRG/WP 02-40241

Mitsui K, Murata A, Kohara M, Tsuchikawa S (2003) Colour modification of wood by light-irradiation and heat treatment In: Abstracts of the First European Conference on Wood Modification, Belgium.

Mitsui K, Takada H, Sugiyama M, Hasegawa R (2001) Changes in the properties of light-irradiated wood with heat treatment: Part 1 Effect of treatment conditions on the change in colour. Holzforschung 55: 601-605

Nikolov S, Encev E (1967) Effect of heat treatment on the sorption dynamics of Beech wood, Nauc. Trud. Lesoteh. Inst., Sofija (Ser. meh. Tehn. Darv.). 14, (3): 71-77

Nuopponen M, Vuorinen T, Jamsä S, Viitaniemi P (2004) Thermal Modifications in Softwood Studied by FT-IR and UV Resonance Raman Spectroscopies. J Wood Chem Technol 24:13-26

Patzelt M, Emsenhuber G, Stingl R (2003) Colour Measurement as means of Quality Control of Thermally Treated Wood, In: Abstracts of the First European Conference on Wood Modification, Ghent, Belgium.

Rapp A, Sailer M (2001) Oil-heat treatment of wood in Germany- State of the art. In: Review on heat treatments of wood. Proceedings of the special seminar on heat treatments, 9 February 2001, Antibes, France. Ed. Rapp, A.O. Office for Official Publications of the European Communities,Luxembourg. pp. 47-64 
Rusche H (1973a) Thermal Degradation of wood at temperatures up to $200{ }^{\circ} \mathrm{C}$ : Part I Holz Roh-Werkst 31 : $273-281$

Rusche H (1973b) Thermal Degradation of wood at temperatures up to $200{ }^{\circ} \mathrm{C}$ : Part II Holz Roh-Werkst 31: $307-312$

Sehistedt-Persson (2003) Colour responses to heat treatment of extractives and sap from pine and spruce. $8^{\text {th }}$ International IUFRO Wood Drying Conference, Brasov, Romania 459-464

Sivonen H, Maunu S, Sundholm F, Jämsa S, Viitaniemi P (2002) Magnetic Resonance Studies of Thermally Modified Wood. Holzforschung 56:648-654

Stamm A, Burr H, Kline A (1946) Stayb-wood-A heat stabilized wood, Ind. Eng Chem 38 (6): 630-634

Stamm A, Hansen L (1937) Minimizing wood shrinkage and swelling: Effect of heating in various gases, Ind. Eng Chem 29 (7): 831-833

Sundqvist B (2004) Colour changes and acid formation in wood during heating. Doctoral Thesis. Lulea University of Technology.

Sundqvist B, Morén T (2002) The influence of wood polymers and extractives on wood colour induced by hydrothermal treatment. Holz Roh-Werkst 60:375-376

Tiemann H (1920) Effect of different methods of drying on the strength and hygroscopicity of wood. 3 rd ed. The kiln drying of lumber, Chap. 11, J. P. Lippincott Co

Tjeerdsma B, Boonstra M, Pizzi A, Tekely P, Militz H (1998) Characterisation of thermally modified wood: molecular reasons for wood performance improvement. Holz Roh-Werkst 56: 149-153

Viitanen H, Jämsä S, Paajanen L, Nurmi A, Viitaniemi P (1994) The effect of heat treatment on the properties of spruce IRG/WP 94-40032, 4p

Viitaniemi P, Jämsä S, Viitanen H (1997) Method for improving biodegradation resistance and dimensional stability of cellulosic products. United States Patent No 5678324 (US005678324)

Wang J, Cooper P (2005) Effect of oil type, temperature and time on moisture properties of hot oil-treated wood. Holz Roh-Werkst 63:417-422

Wikberg H, Maunu S (2004) Characterisation of thermally modified hard- and softwoods by 13C CPMAS NMR. Carbohydrate Polymers 58: 461-466

Yildiz S (2002) Effects of heat tratment on water repellence and anti-swelling efficiency of beech wood Int Res Group Wood Pre, Section 4-Processes, Nº IRG/WP 02-40223

acknowledgement is given to the original source of publication and a link is inserted to the published article on Springer's website. The link must be accompanied by the following text: "The original publication is available at www.springerlink.com". 